Science Life

\title{
THE NATIONAL POLICY OF PUBLIC HEALTH AND NUTRITION IN LATVIA
}

\author{
Inga Šmate*, Ilze Straume** and Jolanta Skrule*,*** \\ * Centre for Disease Prevention and Control of Latvia, Duntes iela 22, Rīga, LV-1005, LATVIA; \\ inga.smate@spkc.gov.lv \\ ** Ministry of Health, Brīīibas iela 72, Rīga, LV-1011, LATVIA; \\ ilze.straume@vm.gov.lv \\ *** The Department of Public Health and Epidemiology, Rīga Stradiṇš University, Kronvalda bulv. 9, Rīga, LV-1070, LATVIA; \\ jolanta.skrule@spkc.gov.Iv
}

\section{DIETARY HABITS IN LATVIA}

Nutrition has a crucial role in improving and maintaining good health status. Unhealthy diet and low physical activity level are among the main risk factors of chronic conditions, such as cardiovascular disease, hypertension, diabetes, stroke, specific cancers and musculoskeletal disorders. Therefore, it is important to monitor dietary habits of the population and implement effective and appropriate nutrition policy.

Analysis of survey data about dietary habits and awareness of the Latvian population was conducted in Latvia during the last five years: Health Behaviour among Latvia's Adult Population 2010 - FINBALT survey $(\mathrm{n}=3010,15-64-$ year-olds); Health Behaviour in School-aged Children HBSC survey 2010 ( $\mathrm{n}=4500,11$-, 13 - and 15-years-olds); Eurobarometer 2009 ( $\mathrm{n}=1018,15+$ year-olds); and DNB Latvian Barometer 2012 ( $\mathrm{n}=1003,18-74$-year-olds); the Study of Children's Anthropometric Habits and the School Environment 2010 ( $n=4285,7-8$-year-olds), description of the situation, and analysis of policy planning documents and implemented activities.

Data from surveys show that some dietary habits of Latvian inhabitants are changing, but most have unhealthy habits. In the last year, some eating habits have improved (Rozentāle u.c., 2010). There are gender differences: men have poorer dietary habits than women, for example, low intake of vegetables, high consumption of salt (Pudule u.c., 2011). Gender differences occur also at school age as well: girls have healthier dietary habits than boys. For example, girls less frequently than boys consume chips and soft drinks. Prevalence of healthy dietary habits decrease between the ages 11 and 15 (Candace et al., 2012).

According to the DNB Latvian barometer survey (2012), one-third (32.4\%) of the adult population in Latvia consider that they have healthy eating habits. According to the Eurobarometer survey (2009) healthy, diet awareness of inhabitants of EU member states is fairly similar - with a very slight improvement in awareness, compared to that in 2005. 60 per cent of respondents in Latvia believe a healthy diet is mostly about "eating more fruit and vegetables". The next frequently reported statements about healthy diet are "eating organic food" (LV - 40\%, EU average - only $10 \%)$, "eating of a variety of different foods/balanced diet" ( $\mathrm{LV}-26 \%$, EU average - 56\%), "avoiding/not eating too much salt". A healthy diet principle was mentioned only by $6 \%$ of respondents in Latvia (EU - 24\%) (Anonymous, 2010). The results indicate that there is a need for more educational activities in the society about healthy eating habits.

The World Health Organisation recommends consuming daily at least $400 \mathrm{~g}$ vegetables and fruit (Anonymous, 2003). However, only $35.3 \%$ of Latvian adults (15-64year-olds) consume fresh vegetables every day (Pudule u.c., 2011). According to the FINBALT survey (2010), fresh vegetables are used daily by $29.3 \%$ of men and $41.1 \%$ of women; boiled vegetables are used daily by $5.2 \%$ of men and $7.4 \%$ of women. According to vegetable consumption by place of residence, daily consumption of fresh vegetables is less prevalent among respondents living in rural areas (27.7\%), compared with respondents living in the capital city Rīga (46.2\%) (Fig. 1). Daily consumption of fresh vegetables varies in respect of respondents' education as well. Consumption of fresh vegetables was increased in persons with higher education (Pudule u.c., 2010). Daily consumption of fruit and berries is only $21.5 \%$. Also, similar to the gender differences for vegetables, $16.4 \%$ of men and $26.3 \%$ of women used fruit and berries on a daily basis (Pudule u.c., 2011).

Salt consumption is one of the indicators of healthy eating habits. High consumption of salt is a very important risk factor of cardiovascular diseases (Strazzullo et al., 2009). The average amount of salt consumed by Latvian inhabitants every day is $7.1 \mathrm{~g} /$ per day, which exceeds the recommended daily amount of $5 \mathrm{~g} /$ per day (Joffe u.c., 2009). The main recommendation for the population is to minimise ad- 


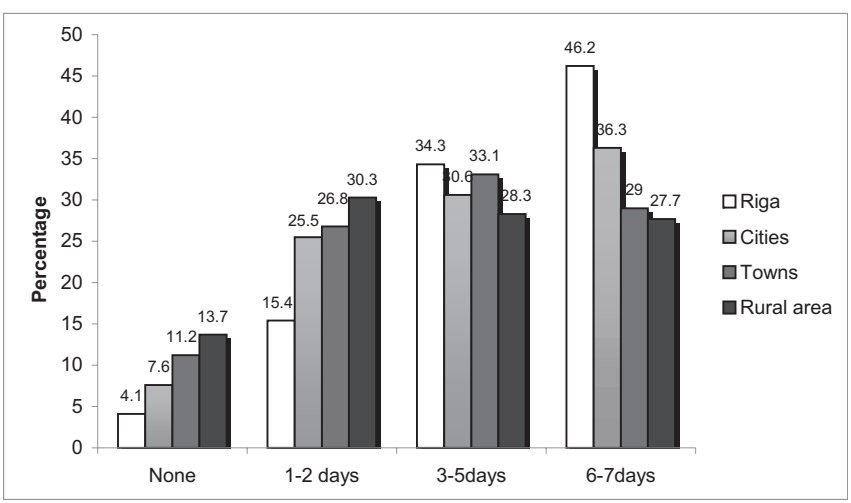

Fig. 1. Consumption of fresh vegetables during the last week by urbanization, 2010 (proportion of respondents). Data source: Health behaviour among Latvian adult population, FINBALT survey, 2010.

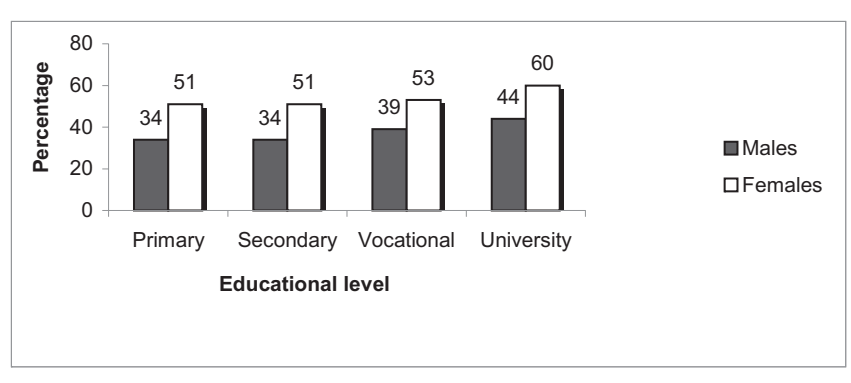

Fig. 2. Reported changes in dietary and other habits during the last year due to health by sex and level of education, 2010 (proportion of respondents). Data source: Health behaviour among Latvian adult population, FINBALT survey, 2010.

dition of salt to food. According to the FINBALT survey (2010), only $33.1 \%$ of males and $49.8 \%$ of females do not add salt to food, and almost every tenth man $(9.0 \%)$ adds salt to food before tasting it, women do that less frequently — 4.3 (Pudule u.c., 2011).

Survey data indicated that almost half (46\%) of the adult population changed dietary habits during the last year due to health. There was a gender difference as well $-38 \%$ men and $55 \%$ women reported changes in dietary habits. Inhabitants with a higher level of education and from urban areas are more prone to changing their dietary habits (Pudule et al., 2010) (Fig. 2). The most frequently changed dietary habits were: increased vegetable consumption $(20.6 \%$ men, $36.6 \%$ women), reduction of fat consumption ( $12.8 \%$ men, $26.4 \%$ women), and reduction of salt intake $(8.6 \%$ men, $16.5 \%$ women). No gender difference in lower alcohol consumption was noted (14.7\% men, $13.2 \%$ women) (Pudule u.c., 2011). (Fig. 3). Consumption of alcohol is one of the main public health problems in Latvia. In 2008, pure alcohol consumption (age 15+) was 13.2 litres per capita (EU average was 10.83 litres) (Anonymous, 2012).

During teenage years, the need for nutrients increases for physiological reasons, and therefore, the nutritional value and balance of consumed food are very important. Promoting the choice of healthy diet among school students is very important. A survey (2010 (Candace et al., 2012) showed that the proportion of students who eat fruit daily in Latvia

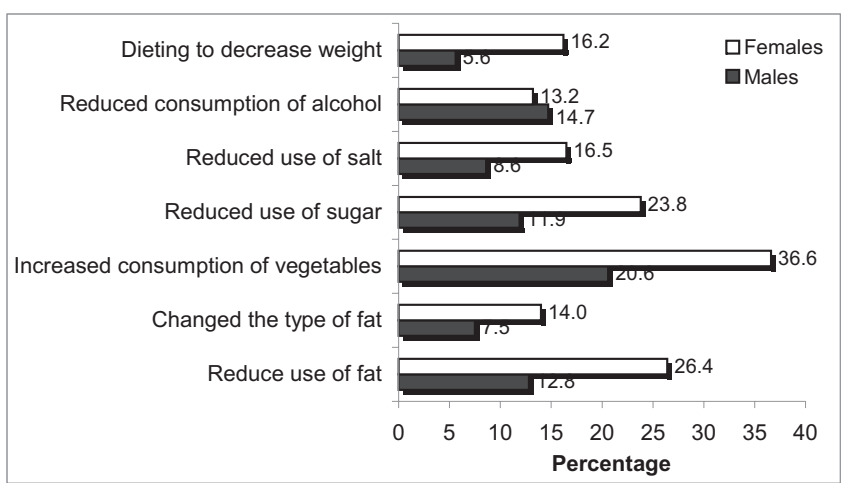

Fig. 3. Reported changes in dietary and other habits during the last year due to health by sex, 2010 (proportion of respondents). Data source: Health behaviour among Latvian adult population, FINBALT survey, 2010.

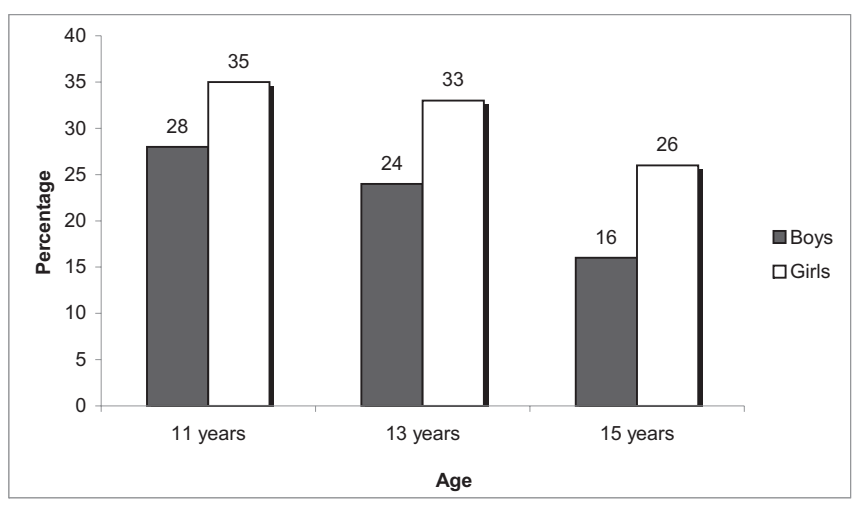

Fig. 4. Consumption of fruit at least once per day during the last week, 2009/2010 (proportion of respondents). Data source: Health Behaviour in School-aged Children, HBSC survey, 2010 (Candace et al., 2012).

is low, in comparison with other HBSC countries. At the age of 11 daily eating of fruit is mentioned by $28 \%$ boys and $35 \%$ girls, and at age 15 by only $16 \%$ boys and $26 \%$ girls (Candace et al., 2012) (Fig. 4). A cafeteria or food shop exists in almost every second $(46.7 \%)$ Latvian comprehensive school, and a food and drink vending machine - in $12.4 \%$ of schools, where students can purchase predominantly sweets and calorie-rich treats (Rubana u.c., 2008).

Unhealthy nutrition in childhood promotes prevalence of obesity, which causes serious health and social problems in the future life of the child (Anonymous, 2012). In the pre-school age, one-fifth of primary school children aged 7-8 (22.9\%) (in Rīga even $28.2 \%$ ) have overweight or obesity and, moreover, its proportion among boys is larger than among girls. The greatest proportion of primary school children with overweight was observed in Rìga and large cities. One of ten primary school children in Latvia is underweight, most often in small towns and in rural areas (Velika u.c., 2011). Several studies performed in other countries prove that food product advertising influences children's tastes, shopping habits and food consumption. Even a 30-second-long advertisement can significantly influence the choice of food by a two-years-old children. Studies have proven that TV advertising is linked with obesity of children aged 2 to 18 (Branca et al., 2007). 
ACTIONS IN THE PUBLIC HEALTH STRATEGY OF LATVIA FOR 2011-2017 THAT ARE RELATED WITH NUTRITION

\begin{tabular}{|c|c|c|c|c|c|}
\hline & Performance indicators & \multicolumn{2}{|c|}{ Reference level } & \multicolumn{2}{|c|}{ Expected indicators } \\
\hline \multirow[t]{2}{*}{$\begin{array}{l}\text { Action result } \\
\text { B1: An action plan for restricting alcohol con- } \\
\text { sumption has been elaborated and implemented }\end{array}$} & $\begin{array}{l}\text { The consumption of absolute alcohol per one inhab- } \\
\text { itant older than } 15 \text { years (in litres) } \\
\text { (source: CSB) }\end{array}$ & 7.0 & 2009 & 6.9 & 6.7 \\
\hline & $\begin{array}{l}\text { Proportion of school students, who during the last } \\
\text { month have drunk more than } 5 \text { units of alcohol on } \\
\text { one occasion (\%) } \\
\text { (source: ESPAD) }\end{array}$ & 29 & 2007 & 25 & 20 \\
\hline $\begin{array}{l}\text { Action result B2: The amount of trans-acids in } \\
\text { the products distributed in Latvia has been re- } \\
\text { stricted }\end{array}$ & $\begin{array}{l}\text { Restrictions to the use of trans-acids defined in le- } \\
\text { gal acts. }\end{array}$ & - & 2010 & $\mathrm{X}$ & $\mathrm{X}$ \\
\hline \multirow[t]{2}{*}{$\begin{array}{l}\text { Policy outcome C1: The health condition of } \\
\text { children improves }\end{array}$} & $\begin{array}{l}\text { Infant mortality (per } 1000 \text { live births) } \\
\text { (source: CSB) }\end{array}$ & 5.7 & 2010 & 5.0 & 4.6 \\
\hline & $\begin{array}{l}\text { Proportion of children ( } 15 \text { years), who assess their } \\
\text { health status as good }(\%) \\
\text { (source: HBSC) }\end{array}$ & 76.4 & 2010 & 78 & 80 \\
\hline \multirow{2}{*}{$\begin{array}{l}\text { Action result C1: Parents informed about the } \\
\text { impact of addiction inducing substances upon } \\
\text { the health of a pregnant woman and foetus and }\end{array}$} & Proportion of pregnant women who smoke (\%) & 10.2 & 2010 & 9 & 8 \\
\hline & Proportion of infants who are breast-fed till the age & 52.5 & 2010 & 53.7 & 56.7 \\
\hline
\end{tabular}
the health of a pregnant woman and foetus and the importance of mother's milk to ensure child's of 6 months $(\%)$

health

\section{MEASURES TO PROMOTE HEALTHY NUTRITION IN LATVIA}

Unhealthy nutrition as a risk factor for non-infectious diseases is one of the priorities in the political agenda in Latvia. The main document of public health in Latvia is the Public Health Strategy for 2011-2017. It is a medium-term policy planning document, developed to continue the implementation of public health policy, to set new development aims and to define lines of actions to reach them, and to maintain, improve and restore the health status of Latvian population during the coming seven years. The main aim of public health policy is to prolong the healthy life years of the Latvian population and to prevent premature death, and to maintain, improve and restore health. The main lines of activities for reaching the set aim are reducing health inequalities, reducing the risk factors of non-infectious diseases (including healthy nutrition), improving of health of mother and child (including breast feeding), decreasing environmental risks, prevention of infection diseases (including safe food), and accessibility of health care (Table 1).

To promote consumption of healthy food in society the guidelines "Healthy Nutrition 2003-2013" and a plan for implementing the guidelines "Healthy Nutrition 20032013" has been approved. The main tasks defined in this document are informing society about issues of healthy nutrition and developing nutritional recommendations for different social groups, integrating issues of healthy nutrition in comprehensive secondary education programmes, as well as other measures.

To promote healthy nutrition, various actions have been taken, including changes in legislation. Several political documents have been adopted. The Implementation Plan of Measures to Supply Fruit and Vegetables to Schools (20102013) aims to increase the consumption of fresh fruit and vegetables by the students of institutions of comprehensive education). The Regulations of Cabinet of Ministers, "Hygiene requirements for institutions of comprehensive primary, comprehensive secondary and vocational education" (2006) and "Hygiene requirements for institutions of education implementing pre-school education programmes" (2006), aim to restrict the availability in educational establishments of food products that are unnecessary in a children's daily diet (chips, salty nuts, coloured candies, sweetened and coloured beverages) and to prohibit distribution of beverages, sugar confectionery and chewing gums, and food containing certain food additives (colourings, sweeteners, preservatives and other substances), as well as food products with high concentration of salt.

The aim of the Regulation of Cabinet of Ministers, "Nutritional norms for pupils in educational institutions, social care and social rehabilitation institutions clients and medical institutions patients" (2012) is to ensure that children in kindergartens, pupils in primary and secondary schools, patients in medical institutions (hospitals) and social care and social rehabilitation institutions receive a balanced diet, as 
well as to promote healthy eating habits to reduce the risk of communicable and non-communicable diseases. The Regulation defines energy and nutrient standards, the amount of salt and sugar added to meals and also food products that need to be included (for example, fresh vegetables, fruits, milk, etc.) or excluded from daily diet (for example French fries, sausages, dried, smoked, salted meat, fish or meat products, frozen meatballs, fish fingers, etc.).

To promote the accessibility of healthy food at institutions of education, in 2007 the Ministry of Health prepared a handbook Preparing Balanced Menus for Pupils of Grades $1-4$, intended for free-of-charge distribution to all catering blocks at the institutions of education. The handbook contains practical recipes for making not only delicious, but also healthy school lunches, so that the lunch would contain all necessary nutrients.

Since 2004, the support programme for supplying specific milk products to students of institutions of comprehensive education, or the so-called "School Milk" programme, has been in operation in Latvia. The European Commission funds the programme. Its basic aim is linked with the promotion of a healthy diet and milk consumption among school students. In the school year 2010/2011, the programme for supplying fruit and vegetables to schools, or "The School Fruit", was introduced, with the aim of promoting higher consumption of fruit and vegetables among school students.

Since 2003, an education programme in nutrition science is offered at the Rīga Stradiņš University, and also since 2006 - a health science Master's degree in nutrition (in the framework of the inter-institutional academic master level programme "Nutrition Science"). Nutrition specialists participate in health promotion, education, treatment and rehabilitation at hospitals, institutions of education, health centres, food production and catering companies, etc. However, thus far, nutrition specialists have been insufficiently involved in performing these duties.

There is the Nutrition Council working at the national level as well, with the aim to promote nutrition policy, analyse the situation and to provide advice for solution of public health problems related with unhealthy nutrition. This council involves working representatives from different ministries, state and municipal institutions, the private sector and nongovernmental organisations.

\section{REFERENCES}

Anonymous (2003). Diet, Nutrition and the Prevention of Chronic Diseases. WHO Technical Report Series 916, report of a joint WHO/FAO expert consultation. Geneva: World Health Organization, 148 pp.

Anonymous (2011). Public Health Strategy for 2011-2017. Cabinet of Ministers Order No. 504 of 5 October 2011. Ministry of Health of the Republic of Latvia.

http://phoebe.vm.gov.lv/misc_db/web.nsf/626e6035eadbb4cd852564990 06b15a6/ab75e1a6c38b637dc22573d800293aaa/\$FILE/POamatnostadne s_eng_pdf.pdf

Anonymous (2010). Special Eurobarometer 329 - Health Determinants. Eurobarometer 72.3 wave, conducted by TNS Opinion \& Social at the request of Directorate General Health and Consumers. 60 pp.

Anonymous (2012). European Health for all database, WHO. http://data.euro.who.int/hfadb/

Branca, F., Nikogosian, H., Lobstein, T. (eds.) (2007). The Challenge of Obesity in the WHO European Region and the Strategies for Response. World Health Organization, $339 \mathrm{pp}$.

Candace, C., Zanotti, C., Morgan, A., Currie, D., de Looze, M., Roberts, C., Samdal, O., Smith, O.R.F., Barnekow, V. (2012). Social Determinants of Health and Well-being Among Young People: Health Behaviour in School-Aged Children (HBSC) study: international report from the 2009/2010 survey. World Health Organization, 252 pp.

Pomerleau, J., Knai, C., Branca, F., Robertson, A., Rutter, H., McKee, M., Brunner, E. \& the EURO-PREVOB Consortium (2008). Review of the literature of obesity (and inequalities in obesity) in Europe and of its main determinants: nutrition and physical activity. $53 \mathrm{pp}$.

http://prevob.1shtm.ac.uk/D3.1.pdf (last accessed 20 July 2012).

Joffe, R., Ozoliņ̌̌, G., Šantare, D., Bartkevics, V., Mike, L., Brikša, I. (2009). Latvijas iedzìvotāju visaptverošais pārtikas patērina pētījums 2007.-2009 [The National Food Consumption Survey of Latvia, 2007-2009]. Rìga: Nacionālais diagnostikas centrs, PVD Pārtikas centrs, 115 lpp.

Pudule, I., Villeruša, A., Grīnberga, D., Velika, B., Taube, M., Behmane, D., Dzērve, V., Prättälä, R. (2011). Latvijas iedzīvotāju veselību ietekmējošo paradumu pétījums, 2010 [Health Behaviour Among Latvian Adult Population, 2010]. Rīga. 173 lpp.

Rozentāle, G., Štāle, M., Zvaigznīte, I. (2010). Sabiedrības veselības stratēéijas mērķu sasniegšanas izvērtējums [Evaluation of Achieving Public Health Strategy Goals]. Rīga: Veselības ekonomikas centrs, 135 lpp.

Rubana, I.M., Velika, B., Grīnberga, D., Pudule, I., Tilgale, N., Trapencieris, M. (2008). Bērnu antropometrisko paradumu un skolu vides pētījums Latvijā [A Study of Children's Anthropometric Habits and School Environment]. Rīga, v/a „Sabiedrības veselỉbas aǵentūra”, 49 lpp.

Strazzullo, P., Lanfranco, D’E., Kandala, N.B., Cappuccio, F.P. (2009). Salt intake, stroke, and cardiovascular disease: Meta-analysis of prospective studies. BMJ, 339; doi: 10.1136/bmj.b4567.

Velika, B., Pudule, I., Grīnberga, D. (2011). Bērnu antropometrisko paradumu un skolu vides pétījums Latvijā [A study of children's Anthropometric Habits and School Environment in Latvia]. Rīga: Veselības ekonomikas centrs, 41 lpp.

\section{NACIONĀLĀ SABIEDRĪBAS VESELĪBAS UN UZTURA POLITIKA LATVIJĀ}

Uzturam ir būtiska nozīme, lai uzlabotu un saglabātu labu veselību. Pētījumu dati liecina, ka Latvijas iedzīvotāju uztura paradumi mainās, tomēr vēl joprojām tie kopumā vērtējami kā neveselīgi. Galvenais sabiedrības veselības politikas dokuments Latvijā ir „Sabiedrības veselības pamatnostādnes 2011.-2017. gadam". Tas ir vidēja termiṇa politikas plānošanas dokuments, kas izstrādāts, lai turpinātu sabiedrības veselības politikas ieviešanu: izvirzītu jaunus attīstības mērḳus, kā arī norādītu rīcības virzienus to sasniegšanai, un saglabātu, uzlabotu un atjaunotu Latvijas iedzīvotāju veselības stāvokli nākamajos septiņos gados. Galvenais stratēǵijas mērkis ir pagarināt Latvijas iedzīvotāju veselīgi nodzīvotā mūža ilgumu un novērst priekšlaicīgu nāvi, saglabājot, uzlabojot un atjaunojot veselību. Galvenie rīcības virzieni, lai šo mērḳi sasniegtu, ir mazināt nevienlīdzību veselības jomā, mazināt neinfekcijas slimību riska faktoru, t.sk. neveselīga uztura, izplatību, uzlabot mātes un bērna veselību, t.sk. veicināt zīdī̌anu, mazināt vides riska faktoru ietekmi, mazināt saslimstību ar infekcijas 
slimībām, t.sk. uzraudzīt pārtikas drošību, uzlabot veselības aprūpes pieejamību. Veselīga uztura lietošanas veicināšanai sabiedrībā Ministru kabinets ir apstiprinājis pamatnostādnes „Veselīgs uzturs 2003.-2013.” un plānu pamatnostādṇu „Veselīgs uzturs 2003.-2013.” ieviešanai. Šo dokumentu galvenie uzdevumi ir informēt sabiedrību par veselīga uztura jautājumiem, izstrādāt uztura ieteikumus dažādam sabiedrības grupām, integrêt veselīga uztura jautājumus vispārējās vidējās izglīīibas programmās u.c. pasākumi. Nacionālā līmenī darbojas arī Uztura padome, kuras mērkis ir veicināt uztura politikas īstenošanu, analizējot ar uzturu saistītās sabiedrības veselības problēmas un sniedzot priekšlikumus šo problēmu risināšanai. Uztura padomē darbojas pārstāvji no dažādām ministrijām, valsts un pašvaldību institūcijām, privātā sektora un nevalstiskajām organizācijām. Sabiedrības veselībā ir noteiktas prioritātes līdz 2017. gadam. Veselīga uztura veicināšana kā viens no galvenajiem neinfekcijas slimību attīstību ietekmējošiem faktoriem ir viena no prioritārām problēmām sabiedrības veselības politikā. 